Keywords:

Eucalyptus

Fertilization

Water deficit

Forest nutrition

Drought

Historic:

Recebido 02/|2/201 I

Aceito 29/04/2014

Palavras chave: Eucalipto

Adubação

Déficit hídrico

Nutrição florestal

Seca

Correspondence: ariadne_lopo@yahoo.com.br
Ariadne Felício Lopo de Sá', Sérgio Valiengo Valeri², Mara Cristina Pessoa da Cruz², José Carlos Barbosa², Gustavo Machado Rezende², Matheus Pozzetti Teixeira ${ }^{2}$

\section{EFFECTS OF POTASSIUM APPLICATION AND SOIL MOISTURE ON THE GROWTH OF Corymbia citriodora PLANTS}

ABSTRACT: The objective of this work was to evaluate the effects of potassium and soil moisture levels on the growth of Corymbia citriodora plants. Four doses of potassium were applied $\left(0,40,80\right.$ and I $\left.20 \mathrm{mg} \cdot \mathrm{dm}^{-3}\right)$ and three soil moisture levels were established (50-80\%, $65-80 \%$ and $80 \%$ of maximum soil field capacity). The experiment was a 4 x 3 factorial arrangement of treatments within a randomized complete design with six replications for each treatment and one pot with two plants for each plot. At 90 days after planting, the plant growth parameters: survival rate, height, stem diameter, leaf area, relative chlorophyll concentration, leaf dry mass, stem and branches dry mass, root dry mass, total dry mass and leaf macronutrient contents were measured. High soil moisture content is necessary for Corymbia citriodora seedlings at nursery stage. Effects of the $\mathrm{K}$ doses were not observed in plants, even when they were cultivated in a soil with a low content of this nutrient.

\section{EFEITOS DA APLICAÇÃO DE POTÁSSIO E UMIDADES DO SOLO NO CRESCIMENTO DE PLANTAS DE Corymbia citriodora}

RESUMO: Conduziu-se este trabalho, com o objetivo de avaliar os efeitos de doses de potássio e umidades do solo no crescimento de plantas de Corymbia citriodora. Foram aplicadas quatro doses de potássio $\left(0,40,80\right.$, e $\left.120 \mathrm{mg} \cdot \mathrm{dm}^{-3}\right)$ e promovidas três níveis de umidades do solo $(50-80 \%, 65-80 \%$ e $80 \%$ do volume máximo de água retido pelo solo em vaso), combinadas em um esquema fatorial $4 \times 3$. O delineamento experimental foi inteiramente casualizado com seis repetições, e cada parcela foi composta por um vaso contendo duas plantas. Aos 90 dias após o plantio, foram avaliados: porcentagem de sobrevivência, altura, diâmetro do caule, área foliar, teor relativo de clorofila, massa de matéria seca de folhas, de caule e ramos, de raízes e total, e teor de macronutrientes nas folhas. Mudas de Corymbia citriodora necessitam de alta umidade do solo na fase de viveiro. Não foram observados efeitos das doses de potássio nas plantas, mesmo quando a concentração desse nutriente no solo era baixa. 


\section{INTRODUCTION}

During the last years, the increasing demand for timber has led to a more intense cultivation of fast growth forest species such as Corymbia citriodora, whose timber has been used especially for construction. The process of commercial forestry expansion has occurred in areas subjected to severe water and nutrients deficit. Abiotic stresses may be responsible for the decrease of up to $82 \%$ of the maximum yield potential of a crop (BRAY et al., 2000).

Potassium, the nutrient which most restricts the Eucalyptus yield in Brazil (SGARBI, 2002), can improve drought tolerance of these plants (CAKMAK, 2005). The need for major amounts of potassium in the soil for the cultivation of nine Eucalyptus hybrids, in nursery conditions, under controlled water deficit was confirmed by Teixeira et al. (1995). K acts as root signal cooperating to deeper rooting toward the remaining moisture in soil. This nutrient also improves cell membrane stability that is essential for cell elongation of shoot and roots. As a consequence, $\mathrm{K}$ increases plant total dry mass production under drought stress. Moreover, sufficient $\mathrm{K}$ status can contribute for greater water retention in plant tissues due to its ability to promote osmotic adjustment and its role in turgor regulation during stomatal movement that affects transpiration and photosynthetic rates and xylem hydraulic conductance. Some reports have also indicated a positive correlation between $\mathrm{K}$ uptake and water acquisition in plants (WANG et al., 20l3).

In addition, under water stress, amongst others types of stress, there is a greater reactive oxygen species production (HASEGAWA et al., 2000), which increases the demand for $\mathrm{K}$ and induces its high accumulation in plant tissues (BERKOWITZ; CHRISTA, 1985). Adequate amounts of $\mathrm{K}$ reduces NADPH oxidase activity, which represents the second major source for ROS production, and protect chloroplasts as ROS production is restricted (CAKMAK, 2005).

The objective of this work was to evaluate the effects of different potassium doses and soil moisture levels on the growth of Corymbia citriodora (Hook.) K. D. Hill \& L. A. S. Johnson plants.

\section{MATERIAL AND METHODS}

The experiment was conducted in greenhouse conditions at the Experimental Nursery of Ornamental and Forest Plants of the College of Agricultural and Veterinary Sciences (FCAV), São Paulo State University (UNESP), Jaboticabal Campus, Brazil.
Seeds, collected in the Campus, were planted in hard plastic pots (containers) of $50 \mathrm{~cm}^{3}$ volume for the formation of the $C$. citriodora seedlings.

For the experiment, black plastic pots with a volume of $5 \mathrm{dm}^{3}$ were covered with newspaper sheets. The covering was made in order to avoid substrate warming due to absorption of solar radiation.

The substrate used was Dystrophic Red Latosol (Oxysol) collected from a depth of 0 to $20 \mathrm{~cm}$ in an area where the soil had not been cultivated for 10 years.

The chemical analysis of the soil, according to the methodology described by Raij et al. (1987), showed the results: $P$ (extracted with ion exchange resin), 5 $\mathrm{mg} \cdot \mathrm{dm}^{-3}$; organic matter content (OM), $15 \mathrm{~g} \cdot \mathrm{dm}^{-3} ; \mathrm{pH}$ in $\mathrm{CaCl}_{2}, 4.3 ; \mathrm{K}^{+}, 0.7 \mathrm{mmol}_{\mathrm{c}} \cdot \mathrm{dm}^{-3} ; \mathrm{Ca}^{2+}, 5 \mathrm{mmol}_{\mathrm{c}} \cdot \mathrm{dm}^{-3}$; $\mathrm{Mg}^{2+}, 2 \mathrm{mmol}_{\mathrm{c}} \cdot \mathrm{dm}^{-3} ; \mathrm{H}+\mathrm{Al}, 42 \mathrm{mmol}_{\mathrm{c}} \cdot \mathrm{dm}^{-3}$; CEC with

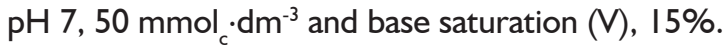

On the basis of recommendations by Raij et al. (1997) for Eucalyptus culture, the potassium doses: 0 , 40,80 and $120 \mathrm{mg} \cdot \mathrm{dm}^{-3}$ were applied, using potassium chloride $\left(60 \%\right.$ of $\left.\mathrm{K}_{2} \mathrm{O}\right)$. Different soil moisture levels were established in order to achieve the percentage limits of the maximum volume of water retained by the soil in the pot: $50 \%$ (low water supply), $65 \%$ (intermediate water supply) and $80 \%$ (high water supply) of the soil field capacity.

Based on the soil chemical analysis results, calcium carbonate $\left(0.549 \mathrm{~g} \cdot \mathrm{dm}^{-3}\right)$ and magnesium carbonate $\left(0.233 \mathrm{~g} \cdot \mathrm{dm}^{-3}\right)$ were applied with the aim to increase the level of soil base saturation (V\%) to $50 \%$. All treatments also received the following nutrient doses in $\mathrm{mg} \cdot \mathrm{dm}^{-3}$ : N (I5); P (I00); B (0.5); Zn (I.0); Cu (0.5); Mn (I.5); and Mo (0.02), according to Raij et al. (1997). The sources were ammonium sulphate, triple superphosphate powder, boric acid, zinc sulphate, copper sulphate, manganese chloride and ammonium molybdate, respectively.

After receiving calcium carbonate, magnesium carbonate and phosphate fertilizer, the soil was transferred into pots and watered in order to achieve $70 \%$ of the soil maximum capacity of water retention, which was maintained during the 30 days of incubation. On the tenth day of incubation, the potassium doses and other nutrients (N, S, B, Zn, Cu, Mn, and Mo) were applied using a solution. At 40 days after the application, the soil was naturally air dried, mixed and sampled for the fertility chemical analysis according to Raij et al. (200I). The final soil volume per pot was $4.73 \mathrm{dm}^{3}$.

Two seedlings about three months old with five pairs of leaves and $28 \mathrm{~cm}$ high were planted per 
pot, and the soil was kept at $70 \%$ of moisture during 30 days. After this period, all treatments were watered to $80 \%$ of the maximum water retention soil capacity and the implementation of three water treatments started (50\%, 65\% and 80\%). Daily weighings were carried out and when the respective treatments reached the limits of $50 \%$ and $65 \%$, they received the appropriate water amount to return to the upper limit of $80 \%$. The treatment regarding the upper limit of $80 \%$ had stable moisture content throughout the whole experiment.

The experiment was conducted for a further 60 days in a $4 \times 3$ factorial arrangement of treatments (four potassium doses and three soil moisture levels) within a randomized complete design with six replications for each treatment and one pot with two plants for each plot.

Growth characteristics: survival rate, height, stem diameter, leaf area, relative chlorophyll concentration, leaf dry mass, stem and branches dry mass, root dry mass, total dry mass and leaf macronutrient contents were measured 90 days after planting.

For the determination of the stem height and diameter, a measuring tape and a digital caliper (Absolute Digimatic, Mitutoyo Corp., Japan) were respectively used. Due to enlargement of stem base caused by the lignotuber development, the diameter was measured at $10 \mathrm{~cm}$ from the soil surface.

The relative chlorophyll concentration was estimated using a portable CCM-200 chlorophyll meter (Opti-Sciences, Tyngsboro, MA, USA). Leaf area was measured with an image analyser (Delta-T Devices, Cambridge, UK).

Different plant parts were packed in paper bags, identified and kept in a forced air circulation heater at approximately $70^{\circ} \mathrm{C}$, until constant weight was achieved and the dry mass determined. The preparation of the leaves for the chemical analysis was performed according to Bataglia et al. (1983).
The determination of leaf macronutrients concentrations followed the methodology described by Sarruge and Haag (1974).

The data obtained at 90 days after planting were subjected to a two-way ANOVA and polynomial regression analysis.

\section{RESULTS AND DISCUSSION}

The potassium doses affected the concentration of the element itself in the soil (Table I). The increment of $\mathrm{K}$ concentration in soil was proportional to the increase of the doses (Figure I). The exchangeable $\mathrm{K}$ contents in the soil were considered low for the control and the dose of $40 \mathrm{mg} \cdot \mathrm{dm}^{-3}$, whereas the doses of 80 and $120 \mathrm{mg} \cdot \mathrm{dm}^{-3}$ were interpreted as intermediate and high $\mathrm{K}$ contents, respectively (RAlJ et al., 1997).

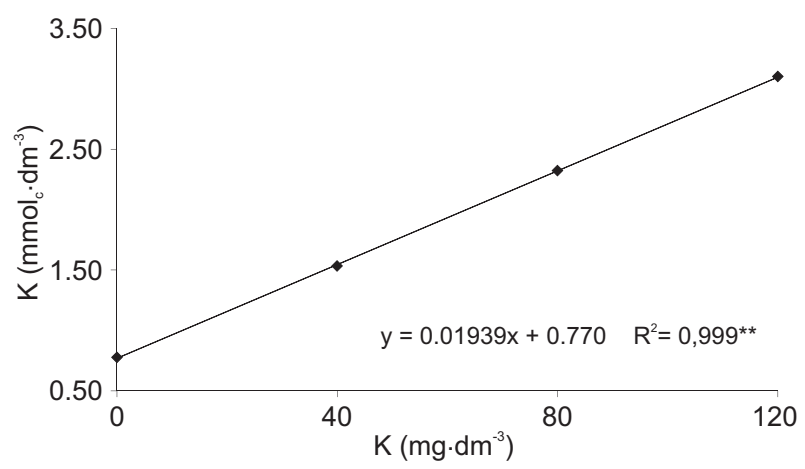

FIGURE I Concentration of potassium in the soil according to the applied doses, after 40 days of incubation.

FIGURA I Concentrações de potássio no solo em função das doses de potássio aplicadas, após 40 dias de incubação.

The base saturation percentage, classified as intermediate (RAIJ et al., 1997), was not altered with the increase of the nutrient in the soil.

TABLE I Chemical characteristics of the soil after nutrient incubation.

TABELA I Características químicas do solo após incubação com nutrientes.

\begin{tabular}{|c|c|c|c|c|c|c|c|c|c|c|}
\hline $\begin{array}{l}\text { K doses } \\
\left(\mathrm{mg} \cdot \mathrm{dm}^{-3}\right)\end{array}$ & $\begin{array}{c}\mathrm{pH} \\
\left(\mathrm{CaCl}_{2}\right)\end{array}$ & $\begin{array}{c}\text { P resin } \\
\left(\mathrm{mg} \cdot \mathrm{dm}^{-3}\right)\end{array}$ & $\begin{array}{c}\mathrm{OM} \\
\left(\mathrm{g} \cdot \mathrm{dm}^{-3}\right)\end{array}$ & $\mathrm{K}^{+}$ & $\mathrm{Ca}^{2+}$ & $\begin{array}{c}\mathrm{Mg}^{2+} \\
--(\mathrm{mm}\end{array}$ & $\begin{array}{l}\mathrm{H}+\mathrm{Al} \\
\left.\mathrm{dm}^{-3}\right)\end{array}$ & BS & CEC & V (\%) \\
\hline 0 & 5.2 & $4 I$ & 17 & 0.8 & 18 & 8 & 26 & 27 & 53 & 51 \\
\hline 40 & 5.3 & 40 & 16 & 1.5 & 17 & 9 & 26 & 28 & 54 & 51 \\
\hline 80 & 5.2 & 41 & 16 & 2.3 & 17 & 9 & 26 & 28 & 54 & 52 \\
\hline \multirow[t]{2}{*}{120} & 5.2 & 41 & 16 & 3.1 & 17 & 9 & 27 & 29 & 55 & 52 \\
\hline & \multicolumn{10}{|c|}{$\mathrm{F}$ test } \\
\hline $\mathrm{K}$ doses & $1.35^{\mathrm{ns}}$ & $2.06^{\mathrm{ns}}$ & $1.86^{\mathrm{ns}}$ & $421.85^{* *}$ & $0.56^{\mathrm{ns}}$ & $\mathrm{I} .0 \mathrm{I}^{\mathrm{ns}}$ & $0.63^{\mathrm{ns}}$ & $\mid .3 I^{\mathrm{ns}}$ & $1.29^{\mathrm{ns}}$ & $0.96^{\text {ns }}$ \\
\hline CV (\%) & 6.69 & 4.84 & 1.44 & 10.70 & 15.33 & 15.84 & 5.80 & 8.13 & 5.82 & 3.90 \\
\hline
\end{tabular}

ns - Non significant $(P>0.05)$, ${ }^{*} *$ Significant $(P<0.0 I)$ by the $F$ test. 
Plant survival was approximately 100\%, independent of the treatment. Only one plant died during the experiment, apparently due to being planted too deep.

The evaluated growth parameters were differently affected by the treatments. In conditions of limited water supply, the plants growth was limited (Table 2).

The decrease in the minimum limit of the soil moisture caused a lower growth in regards to plant height. The treatment of $65 \%$ of moisture resulted in an average plant height $6.7 \%$ shorter than the treatment in which moisture was kept at $80 \%$ (Table 2).

Similar results were found in a number of studies. Eucalyptus hybrids (TEIXEIRA et al., 1995) and water stressed plants of Corymbia citriodora, Eucalyptus pellita, E. camaldulensis, E. cloeziana and E. urophylla (GONÇALVES; PASSOS, 2000) showed a lower height.
The results from the potassium doses for stem diameter growth were better fitted by the quadratic model. According to the derived equation $\left(y=-0.0001 \cdot x^{2}+0.0137 \cdot x+6.403 ; R^{2}=0,720 *\right)$, the maximum diameter growth, equivalent to 6.87 $\mathrm{mm}$, was obtained from the $68.7 \mathrm{mg} \cdot \mathrm{dm}^{-3} \mathrm{~K}$ dose. The increase in diameter was greater with any of the applied potassium doses than with the absence of the nutrient (Table 2).

The increase in diameter was greater with any of the applied potassium doses than with the absence of the nutrient (Table 2). Similar effects were found in Eucalyptus clones that showed diameter growth in response to the nutrient application, but the influence of the potassium on plant height was not verified (AVILA et al., 20I I).

The process of xylem cell differentiation, which is involved on the initial timber formation, requires potassium. Its accumulation in the cell differentiation

TABLE 2 Growth variables of Corymbia citriodora plants according to soil moisture levels associated with potassium doses.

TABELA 2 Variáveis de crescimento das plantas de Corymbia citriodora em função dos limites de umidade do solo associados às doses de potássio.

\begin{tabular}{|c|c|c|c|c|c|c|c|c|c|c|c|}
\hline $\begin{array}{c}\text { Moisture } \\
\text { (\%) }\end{array}$ & $\begin{array}{c}\mathrm{K} \\
\left(\mathrm{mg} \cdot \mathrm{dm}^{-3}\right)\end{array}$ & $\mathrm{H}(\mathrm{cm})$ & $\mathrm{D}(\mathrm{mm})$ & $\mathrm{NL}$ & $\operatorname{LF}\left(\mathrm{cm}^{2}\right)$ & TDM & SDM & $\begin{array}{c}\text { RDM } \\
\left(g \cdot \text { pot }^{-1}\right)\end{array}$ & LDM & DMAP & $\mathrm{RCC}$ \\
\hline 80 & 0 & 95.1 & 6.43 & 70.6 & 1254.3 & 62.29 & 22.17 & 12.27 & 27.86 & 50.03 & 9.33 \\
\hline 80 & 40 & 91.9 & 7.11 & 71.1 & 1376.6 & 67.91 & 23.16 & 14.10 & 30.55 & 53.71 & 10.03 \\
\hline 80 & 80 & 90.4 & 6.68 & 67.0 & 1250.3 & 64.72 & 19.92 & 14.87 & 29.93 & 49.85 & 9.13 \\
\hline 80 & 120 & 94.3 & 7.24 & 78.9 & 1331.0 & 66.92 & 22.76 & 14.07 & 30.09 & 52.85 & 9.10 \\
\hline Means & & 92.9 & 6.86 & 71.9 & 1303.1 & 65.46 & 22.00 & 13.85 & 29.61 & 51.61 & 9.40 \\
\hline 65 & 0 & 91.4 & 6.06 & 88.1 & 1186.2 & 59.69 & 19.85 & 12.23 & 27.61 & 47.46 & 11.10 \\
\hline 65 & 40 & 95.6 & 7.01 & 73.7 & 1232.8 & 62.49 & 20.93 & 14.33 & 27.24 & 48.17 & 8.87 \\
\hline 65 & 80 & 90.9 & 6.76 & 77.0 & 1288.7 & 66.65 & 20.69 & 15.05 & 30.91 & 51.60 & 8.42 \\
\hline 65 & 120 & 91.5 & 6.49 & 67.6 & 1152.9 & 61.22 & 18.66 & 14.48 & 28.08 & 46.74 & 9.67 \\
\hline Means & & 92.3 & 6.58 & 76.6 & 1215.1 & 62.51 & 20.03 & 14.02 & 28.46 & 48.49 & 9.51 \\
\hline 50 & 0 & 91.9 & 6.58 & 77.0 & 1015.5 & 62.49 & 19.92 & 14.96 & 27.62 & 47.53 & 9.55 \\
\hline 50 & 40 & 83.2 & 6.70 & 81.6 & 1143.5 & 62.66 & 19.95 & 13.13 & 29.59 & 49.54 & 10.28 \\
\hline 50 & 80 & 88.2 & 6.70 & 67.8 & 950.6 & 61.28 & 19.32 & 14.45 & 27.52 & 46.83 & 10.40 \\
\hline 50 & 120 & 83.6 & 6.26 & 93.1 & II54.I & 61.90 & 19.35 & 14.55 & 28.00 & 47.36 & 10.40 \\
\hline Means & & 86.7 & 6.56 & 79.9 & 1065.9 & 62.08 & 19.63 & 14.27 & 28.18 & 47.81 & 10.16 \\
\hline & & \multicolumn{10}{|c|}{$\mathrm{F}$ test } \\
\hline \multicolumn{2}{|c|}{ Moisture levels (M) } & $7.77^{* *}$ & $2.64^{\mathrm{ns}}$ & $2.03^{\text {ns }}$ & $3.36^{*}$ & $15.64^{* *}$ & $5.05^{* * *}$ & $0.22^{\mathrm{ns}}$ & $1.67^{\mathrm{ns}}$ & $6.62^{* *}$ & $2.1 I^{\mathrm{ns}}$ \\
\hline \multicolumn{2}{|c|}{$\mathrm{K}$ doses $(\mathrm{K})$} & $1.02^{\mathrm{ns}}$ & $3.96^{*}$ & $1.61^{\mathrm{ns}}$ & $1.29^{\mathrm{ns}}$ & $1.7 I^{\mathrm{ns}}$ & $0.83^{\mathrm{ns}}$ & $1.79^{\mathrm{ns}}$ & $1.28^{\mathrm{ns}}$ & $0.97^{\mathrm{ns}}$ & $0.74^{\text {ns }}$ \\
\hline \multicolumn{2}{|c|}{$K \times M$} & $1.67^{\mathrm{ns}}$ & $2.02^{\mathrm{ns}}$ & $2.52^{*}$ & $1.28^{\mathrm{ns}}$ & $1.47^{\mathrm{ns}}$ & $0.87^{\mathrm{ns}}$ & $1.16^{\mathrm{ns}}$ & $1.24^{\mathrm{ns}}$ & $\left.1.5\right|^{\mathrm{ns}}$ & $2.38^{*}$ \\
\hline \multicolumn{2}{|c|}{ CV (\%) } & 6.66 & 7.72 & 18.07 & 7.76 & 12.43 & 13.46 & 15.82 & 9.96 & 7.82 & 14.24 \\
\hline
\end{tabular}

H: height; D: diameter; NL: number of leaves; LF: leaf area; TDM: total dry mass; SDM: stem and branches dry mass; RDM: root dry mass; LDM: leaf dry mass; DMAP: dry mass of the aerial part of plant; RCC: relative chlorophyll content at 90 days after planting; equations referring to the effects of the soil moisture levels in: $H=0.207 x+77.172 R^{2}=0.819 * *$; $L=7.905 x+680.884 R^{2}=0.978 * * ; T D M=0.1 I 3 x+56.034 R^{2}=0.844 *$; $S M$ $=0.0790 x+15.4233333 R^{2}=0.872 * *$; DMAP $=0.127 x+41.079 R^{2}=0.879 * *$; equation referring to the effects of the potassium doses in: $D=$ $-0.0001 x^{2}+0.0137 x+6.403 R^{2}=0.720 *{ }^{*}$ s - Non significant $(P>0.05)$, * and **- Significant $(P<0.05$ and $P<0.01$, respectively) by the $F$ test. 
area was probably the driving force for cell expansion (LANGER et al., 2002), which resulted in the growth of the stem diameter.

Interaction between soil moisture levels and potassium doses had a significant effect on leaf number (Table 2). However, it was not possible to determine a trend of data in regard to the interaction between the factors when the statistical breakdown of treatments was made. Under water stress, the plants tended to produce fewer or smaller leaves as a way to reduce water loss through transpiration (KOZLOWSKI; PALLARDY, 2002). Although the effect from the water treatment was not distinctly significant on the number of leaves, it is possible to observe, in general, that an increase in leaf number occurred with a water deficit increase, being a result from the decrease in soil moisture.

Water deficiency was followed by a reduction in the leaf expansion (Table 2).

A higher number of leaves from the treatments of $65 \%$ and $50 \%$ of moisture were not enough to control leaf area reduction on plants from these treatments (Table 2). During the experiment, foliar abscission was observed. Furthermore, the leaves formed afterwards had a smaller area than those that had previously fallen, which may be considered as a positive acclimation response to the low water availability (KOZLOWSKI; PALLARDY, 2002).

The production of total plant dry mass decreased with the water deficit. Plants from the treatments that had minimum moisture limits of $65 \%$ and $50 \%$ showed lower total dry mass, and stem and branches dry mass than plants from the treatment that had $80 \%$ of moisture level (Table 2). However, the values were substantially close, which implies that the protection mechanisms against dehydration were efficient in maintaining the water content and the rate of biomass production.

The photosynthetic rate was proportional to leaf area (LAWLOR; TEZARA, 2009). Thus, leaf area reduction may have affected carbon assimilation and, consequently, biomass production. A positive correlation of $0.516 \mathrm{II} * *(P<0.01)$ was verified between leaf area and total dry mass.

Stem and branches dry mass was affected by the water treatment and this variable was probably the main factor that influenced total dry mass and the dry mass of the aerial plant part (Table 2), so that the effect of soil moisture was significant on these variables. The effect of water supply on leaf biomass was not verified.

The potassium effects on the evaluated growth characteristics were not significant, except for stem diameter (Table 2). During the experiment, plant growth was not affected by the low concentrations of potassium found in the soil (RAlJ et al., I997), 0.8 and $1.5 \mathrm{mmol}_{\mathrm{c}}$. $\mathrm{dm}^{-3}$, which are derived from the 0 and $40 \mathrm{mg} \cdot \mathrm{dm}^{-3}$ doses, respectively.

The interaction between soil moisture levels and potassium doses was significant for the relative chlorophyll content, but these factors, when separated, did not have any effect on this parameter (Table 2). The statistical breakdown of potassium doses within the moisture levels did not demonstrate a trend for this interactive effect among the treatments for the relative chlorophyll content.

Nitrogen, calcium and magnesium contents in the leaves (Table 3 ) remained constant, regardless of the moisture levels. These nutrients are mainly absorbed through mass flow. Thus, it is suggested that their absorption actively occurred as soon as the moisture level was restored to $80 \%$ (MALAVOLTA, 2006).

The effect of the water treatments on the phosphorus, leaf potassium and sulfur contents was verified (Table 3). Root ionic absorption of phosphorus and potassium occurs mainly through diffusion and, for sulfur, through mass flow, but water availability limits these processes (MALAVOLTA, 2006). Therefore, it is believed that the absorption and transportation of phosphorus, potassium and sulfur, differently from the other evaluated macronutrients, may be more dependent of an ideal soil moisture condition.

The potassium doses affected only phosphorus and potassium contents. The potassium doses increase led to higher concentration of these nutrients in the leaves, according to the quadratic model for phosphorus and the linear model for potassium (Table 3).

The application of potassium chloride helped to enhance the absorption of this nutrient, but the potassium contents were greater under conditions of high moisture (Figure 2).

The potassium content in the leaves, which is considered appropriate for the Eucalyptus culture, according to Malavolta et al. (1997), varies from 10 to $12 \mathrm{~g} \cdot \mathrm{kg}^{-1}$. Malavolta et al. (1997) classified plants, which have leaf potassium content lower than $8 \mathrm{~g} \cdot \mathrm{kg}^{-1}$ as potassium deficient plants. However, any treatment presented visual symptoms of nutrient deficiency, even when $\mathrm{K}$ contents in leaves were lower than 4 $\mathrm{g} \cdot \mathrm{kg}^{-1}$. In this work, all leaves of C. citriodora young plants were used to analyze the nutrient status while Malavolta et al. (1997) collected third or fourth pair leaves of branches in the upper third of top of the $E$. grandis trees in field. As concentrations of nutrient vary 
TABLE 3 Macronutrient contents in leaves of Corymbia citriodora according to soil moisture levels associated with potassium doses.

TABELA 3 Teor de macronutrientes em folhas de Corymbia citriodora em função dos níveis de umidade do solo associados às doses de potássio.

\begin{tabular}{|c|c|c|c|c|c|c|c|}
\hline $\begin{array}{c}\text { Moisture } \\
(\%)\end{array}$ & $\begin{array}{c}\mathrm{K} \\
\left(\mathrm{mg} \cdot \mathrm{dm}^{-3}\right)\end{array}$ & \multicolumn{6}{|c|}{$\left(\mathrm{g} \cdot \mathrm{kg}^{-1}\right)$} \\
\hline 80 & 0 & 10.88 & 1.52 & 4.89 & 6.44 & 2.53 & 0.89 \\
\hline 80 & 40 & 9.80 & 1.29 & 5.92 & 5.77 & 2.28 & 0.78 \\
\hline 80 & 80 & 9.52 & 1.28 & 8.88 & 6.18 & 2.55 & 0.76 \\
\hline 80 & 120 & 9.40 & 1.28 & 11.22 & 5.92 & 2.20 & 0.80 \\
\hline Means & & 9.90 & 1.34 & 7.73 & 6.08 & 2.39 & 0.80 \\
\hline 65 & 0 & 10.10 & 1.43 & 4.59 & 6.04 & 2.08 & 0.70 \\
\hline 65 & 40 & 9.96 & 1.20 & 6.12 & 6.13 & 2.33 & 0.64 \\
\hline 65 & 80 & 9.55 & 1.16 & 8.29 & 5.99 & 2.08 & 0.70 \\
\hline 65 & 120 & 9.36 & 1.32 & 10.20 & 6.35 & 2.166 & 0.72 \\
\hline Means & & 9.74 & 1.28 & 7.30 & 6.13 & 2.166 & 0.69 \\
\hline 50 & 0 & 9.98 & 1.19 & 3.82 & 5.83 & 2.40 & 0.66 \\
\hline 50 & 40 & 9.34 & 1.10 & 5.70 & 6.00 & 2.31 & 0.65 \\
\hline 50 & 80 & 9.80 & 1.28 & 8.06 & 6.89 & 2.01 & 0.65 \\
\hline 50 & 120 & 10.30 & 1.18 & 9.82 & 6.64 & 2.35 & 0.56 \\
\hline \multirow{2}{*}{\multicolumn{2}{|c|}{ Means }} & 9.86 & 1.19 & 6.85 & 6.34 & 2.27 & 0.63 \\
\hline & & \multicolumn{6}{|c|}{$\mathrm{F}$ test } \\
\hline \multicolumn{2}{|c|}{ Moisture levels (M) } & $0.18^{\text {ns }}$ & $6.00^{* *}$ & $4.37^{*}$ & $0.60^{\text {ns }}$ & $2.88^{\text {ns }}$ & $21.31^{* *}$ \\
\hline \multicolumn{2}{|c|}{$\mathrm{K}$ doses $(\mathrm{K})$} & $2.1 I^{\mathrm{ns}}$ & $4.48^{* *}$ & $118.83^{* *}$ & $0.75^{\mathrm{ns}}$ & $0.57^{\mathrm{ns}}$ & $1.67^{\mathrm{ns}}$ \\
\hline \multicolumn{2}{|c|}{$K \times M$} & $1.37^{\mathrm{ns}}$ & $1.90^{\mathrm{ns}}$ & $0.53^{\text {ns }}$ & $1.05^{\mathrm{ns}}$ & $1.84^{\mathrm{ns}}$ & $1.5 \mathrm{I}^{\mathrm{ns}}$ \\
\hline \multicolumn{2}{|c|}{ CV (\%) } & 9.70 & 12.40 & 14.14 & 14.28 & 14.27 & 13.33 \\
\hline
\end{tabular}

$\mathrm{N}$ : nitrogen; P: phosphorus; K: potassium; Ca: calcium; Mg: magnesium; S: sulfur in leaves at 90 days after planting; equations referring to the effects of the soil moisture levels in: $P=0.005^{*} x+0.928 R^{2}=0.994 * * K=0.0293^{*} x+5.387 R^{2}=0.999 * * ;=0.0058 * x+0.3297 R^{2}=0.962 * *$; equations referring to the effects of the potassium doses in: $P=0.00003 * x^{2}-0.0046 * x+1.366 R^{2}=0.839 * * ; K=0.05 I I * x+4.228 R^{2}=$ 0.99 *** $^{*}$ s - Non significant $(P>0.05)$, * and **- Significant $(P<0.05$ and $P<0.0$ I, respectively) by the $F$ test.

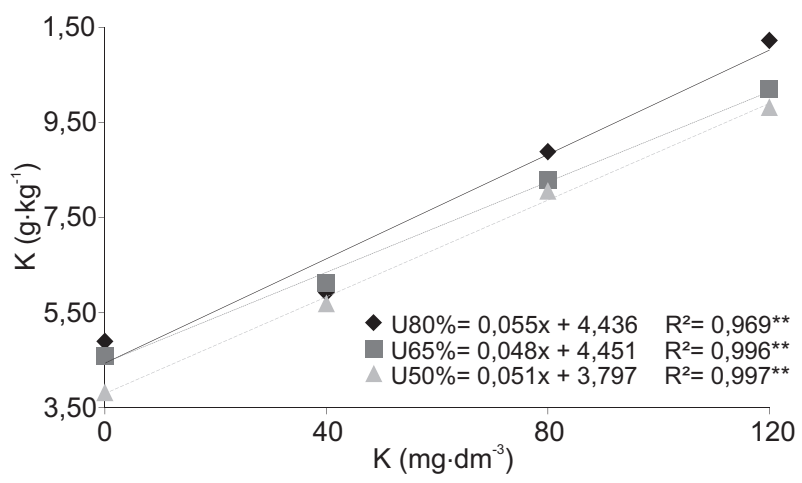

FIGURE 2 Concentration variations of potassium in leaves of Corymbia citriodora according to the potassium doses and soil moisture levels.

FIGURA 2 Variações das concentrações de potássio nas folhas Corymbia citriodora em função das doses de potássio aplicadas e dos limites de umidade do solo promovidos. according to age and species, these differences limits the comparisons.

The highest potassium doses $\left(120 \mathrm{mg} \cdot \mathrm{dm}^{-3}\right)$ in the soil resulted in a greater accumulation of this element in plant tissues. In theory, it should have contributed to the increase and maintenance of the cell turgor, even under conditions of low water potential due to drought (MAHOUACHI et al., 2006). However, in this study, it was not verified that the potassium minimized water stress effects.

Potassium contributes to the osmotic adjustment in plants under low water availability. This characteristic, amongst others, enables this nutrient to minimize the deleterious effects caused by drought (CAKMAK, 2005; MAHOUACHI et al., 2006). Furthermore, the osmotic adjustment slowly develops in response to dehydration. Therefore, it is possible that 
this process did not develop in the plants of this study because of the briefness of the water deficit cycles, which would explain the absence of alleviation of water stress effects associated with potassium.

\section{CONCLUSIONS}

High soil moisture content is necessary for Corymbia citriodora seedlings at nursery stage. Effects of the $\mathrm{K}$ doses were not observed in plants, even when they were cultivated in a soil with a low content of this nutrient.

\section{ACKNOWLEDGEMENTS}

To the State of São Paulo Research Foundation (FAPESP) for the scholarship granted to the first author (Proc. 2009/I2660-0).

\section{REFERENCES}

AVILA, F. S. d'; PAIVA, H. N.; LEITE, H. G.; BARROS, N. F.; LEITE, F. P. Efeito do potássio na fase de rustificação de mudas clonais de eucalipto. Revista Árvore, Viçosa, v. 35, n. I, p. I3-19, 20II.

BATAGLIA, O. C.; FURLANI, A. M. C.; TEIXEIRA, J. P. F.; FURLANI, P. R.; GALLO, J. R. Métodos de análise química de plantas. Campinas: Instituto Agronômico, 1983. 48 p. (Boletim Técnico, 78).

BERKOWITZ, G. A.; CHRISTA, W. Leaf $\mathrm{K}^{+}$interaction with water stress inhibition of nonstomatal-controlled photosynthesis. Plant Physiology, Lanscaster v. 79, p. 189-190, 1985.

BRAY, E. A.; BAILEY-SERRES, J.; WERETILNYK, E. Responses to abiotic stresses. In: GRUISSEM, W.; BUCHANNAN, B.; JONES, R. (Ed.). Biochemistry and molecular biology of plants. Rockville: American Society of Plant Physiologists, 2000. p. II58-1249.

CAKMAK, I. The role of potassium in alleviating detrimental effects of abiotic stresses in plants. Journal of Plant Nutrition and Soil Science, Oldenburg, v. 168, n. 4, p. 521-530, 2005.

GONÇALVES, R. M.; PASSOS, C. M. A. Crescimento de cinco espécies de eucalipto submetidas a déficit hídrico em dois níveis de fósforo. Ciência Florestal, Santa Maria, v. 10, n. 2, p. |45-16I, 2000.

HASEGAWA, P. M.; BRESSAN, R. A.; ZHU, J. K.; BOHNERT, H. J. Plant cellular and molecular responses to high salinity. Annual Review of Plant Physiology Plant Molecular Biology, Palo Alto, v. 5I, p. 463-499, 2000.
KOZLOWSKI, T. T.; PALLARDY, S. G. Acclimation and adaptive responses of woody plants to environmental stresses. The Botanical Review, New York, v. 68, n. 2, p. 270-334, 2002.

LANGER, K.; ACHE, P.; GEIGER, D.; STINZING, A.; AREND, M.; WIND, C.; REGAN, S.; FROMM, J.; HEDRICH, R. Poplar potassium transporters capable of controlling $\mathrm{K}^{+}$homeostasis and $\mathrm{K}^{+}$-dependent xylogenesis. Plant Journal, London, v. 37, p. 9997-I009, 2002.

LAWLOR, D. W.; TEZARA, W. Causes of decreased photosynthetic rate and metabolic capacity in waterdeficient leaf cells: a critical evaluation of mechanisms and integration of processes. Annals of Botany, Oxford, v. I03, p. 56I-579, 2009.

MAHOUACHI, J.; SOCORRO, A. R.; TALON, M. Responses of papaya seedlings (Carica papaya L.) to water stress and re-hydration: growth, photosynthesis and mineral nutrient imbalance. Plant and Soil, The Hague, v. 28I, p. I37-I46, 2006.

MALAVOLTA, E. Manual de adubação de plantas. São Paulo: Agronômica Ceres, 2006. 638 p.

MALAVOLTA, E.; VITTI, E. C.; OLIVEIRA, S. A. Avaliação do estado nutricional das plantas: princípios e aplicações. 2. ed. Piracicaba: Associação Brasileira para Pesquisa da Potassa e do Fosfato, 1997. 319 p.

RAIJ, B.; ANDRADE, J. C.; CANTARELLA, H.; QUAGGIO, J. A. (Ed.). Análises químicas para avaliação da fertilidade de solos tropicais. Campinas: Instituto Agronômico, 200I. 285 p.

RAIJ, B.; CANTARELLA, H.; QUAGGIO, J. A.; FURLANI, A. M. C. Recomendações de adubação e calagem para o Estado de São Paulo. Campinas: Instituto Agronômico/ Fundação IAC, 1997. 285 p. (Boletim Técnico, 100).

SARRUGE, J. R.; HAAG, H. P. Análises químicas em plantas. Piracicaba: ESALQ, 1974. 56 p.

SGARBI, F. Produtividade do Eucalyptus sp. em função do estado nutricional e da fertilidade do solo em diferentes regiões do Estado de São Paulo. 2002. 102 f. Dissertação (Mestrado em Recursos Florestais) - Escola Superior de Agricultura "Luiz de Queiroz", Piracicaba, 2002.

TEIXEIRA, P. C.; LEAL, P. G. L.; BARROS, N. F; NOVAIS, R. F. Nutrición potásica y relaciones hídricas en plantas de Eucalyptus spp. Bosque, Valdivia, v. 16, n. I, p. 6I-68, 1995.

WANG, M.; ZHENG, Q.; SHEN, Q.; GUO, S. The critical role of potassium in plant stress response. International Journal of Molecular Sciences, Basel, v. I4, n. 4, p. 73707390, 2013. 